\title{
Detection of Latent Pernicious Anaemia in Iron-deficiency Anaemia*
}

\author{
J. H. DAGG, M.B., M.R.C.P.ED., M.R.C.P.GLASG. ; A. GOLDBERG, M.D., F.R.C.P.GLASG., F.R.C.P.ED., M.R.C.P. \\ W. N. GIBBS, M.B., B.S. ; J. R. ANDERSON, M.D., M.R.C.P., M.R.C.P.GLASG.
}

Brit. med. F., 1966, 2, 619-621

It has long been recognized that iron-deficiency anaemia and pernicious anaemia may occur in members of the same family (Faber and Gram, 1924 ; Maclachlan and Kline, 1926 ; Witts, 1930 ; Kaufmann and Thiessen, 1939). There are also numerous reports of pernicious anaemia developing in patients with a previous history of iron-deficiency anaemia (Callender and Denborough, 1957). More recently, in a review of 371 patients with iron-deficiency anaemia, Beveridge et al. (1965) found that 12 had overt or latent pernicious anaemia when first seen and that, on follow-up, three further patients developed latent pernicious anaemia and five more the overt disease.

It is now established that a high proportion of patients suffering from Addisonian pernicious anaemia have in their serum an organ-specific antibody to gastric parietal mucosal cells. Using an immunofluorescent technique, Taylor et al. (1962) demonstrated the antibody in $85 \%$ of 100 patients. With a similar technique Dagg et al. (1964) showed that the sera of $13(20.8 \%)$ of 64 patients with iron-deficiency anaemia contained the antibody, compared with only $4(6.4 \%)$ in 64 matched control subjects; this increased incidence in irondeficiency anaemia occurred only in those patients who also had a histamine-fast achlorhydria ; patients with free acid in the gastric juice had no higher incidence than the controls. In addition, Coghill et al. (1965) demonstrated that parietal-cell antibody was found almost exclusively in patients with hypochromic anaemia who also had biopsy evidence of atrophic gastritis. The auto-antibody to gastric mucosa in both pernicious anaemia and achlorhydric iron-deficiency anaemia appears to be identical.

It would clearly be of practical value to be able to predict which patients with iron-deficiency anaemia might later develop pernicious anaemia. Since histamine-fast achlorhydria and antibody to gastric parietal cells occur in most cases of pernicious anaemia, it was thought likely that out of any large group of patients with iron-deficiency anaemia those who had both these tests positive would provide the main pool containing examples of latent pernicious anaemia.

Out of a series of 114 patients presenting with iron-deficiency anaemia 22 were found who were both achlorhydric and had gastric-parietal-cell antibodies. In each of these patients investigations were carried out to detect the presence or absence of latent or overt pernicious anaemia.

\section{Material and Methods}

Clinical Data.-In 112 of the 114 patients with irondeficiency anaemia investigated the diagnosis was confirmed by the peripheral blood picture, absence of stainable iron in the bone-marrow, a characteristically low serum iron, and high total iron-binding capacity. In two patients marrow examination was omitted. The presence of histamine-fast achlorhydria was assessed as described previously (Dagg et al., 1964). In this group of 114 patients $55(47.4 \%)$ had histamine-fast achlorhydria and $59(52.6 \%)$ had free acid. In no case was there evidence of steatorrhoea or a history of gastric surgery.

* From the University Departments of Medicine and Pathology, Western Infirmary, Glasgow.
Antibody Tests.-An immunofluorescent "sandwich" technique was employed, as previously described, to detect parietal-cell antibody in the patient's serum (Dagg et al., 1964), and also to detect antibody to thyroid epithelial microsomes in the serum (Adams et al., 1964). Antibody to thyroglobulin was detected by the tanned-red-cell-agglutination test as described by Fulthorpe et al. (1961), with an initial serum dilution of 1 in 4.

Vitamin- $B_{12}$ Studies.-In the 22 patients with histamine-fast achlorhydria and a positive antibody test the serum vitamin- $B_{12}$ levels were assayed by a modification of the method of Hutner et al. (1956), Euglena gracilis being the test organism. We have found the normal range to be 200 to $1,000 \mu \mu \mathrm{g}$./ml., and values below $140 \mu \mu \mathrm{g} . / \mathrm{ml}$. were regarded as subnormal.

Tests of absorption and excretion of radiocobalt $\left({ }^{58} \mathrm{Co}\right)-$ labelled vitamin $B_{12}$ were also carried out in these patients (Schilling, 1953). After an overnight fast an oral dose of $0.5 \mu \mathrm{c}, 0.5 \mu \mathrm{g}$., ${ }^{58} \mathrm{Co}$-vitamin $\mathrm{B}_{12}$ was given, followed two hours later by $1,000 \mu \mathrm{g}$. of cyanocobalamin intramuscularly. The urine was then collected for the subsequent 24 hours and the total urinary radioactivity expressed as a percentage of the oral dose. The normal value was taken as greater than $7.5 \%$ excretion. Where the test was abnormal it was repeated along with $10 \mathrm{mg}$. of hog intrinsic factor, and, in one patient (Case 3), with normal human gastric juice of known high intrinsic-factor potency. In the same case an assay of intrinsic-factor activity in the gastric juice was carried out after maximal histamine stimulation, using the method described by Gottlieb et al. (1965).

Other clinical data are summarized in the Table.

\section{Results}

\section{Gastric Parietal-cell Antibody}

Tests were positive in $26(22.8 \%)$ out of 114 iron-deficient patients, compared with $4(6.3 \%)$ out of 64 controls $\left(\chi^{2}=8.51\right.$, $\mathrm{P}<0.01)$. Antibody tests were positive in $22(40.8 \%)$ out of 55 patients with histamine-fast achlorhydria and in $4(6.7 \%)$ out of 59 with free acid $\left(\chi^{2}=23.4, P<0.001\right)$.

\section{Schilling Test}

Impaired absorption of ${ }^{58}$ Co-vitamin $\mathrm{B}_{12}$ was demonstrated in seven cases of the 22 ; restoration to normal by administration of intrinsic factor occurred in six of these. In the remaining patient (Case 3 ) absorption was not improved by intrinsic factor nor by gastric juice of known high intrinsicfactor potency, but no intrinsic-factor activity was found in the gastric juice by the technique of Gottlieb et al. (1965); she was therefore considered to have latent pernicious anaemia. In the remaining 15 patients the Schilling test was normal.

\section{Serum Vitamin $\mathbf{B}_{12}$}

This was reduced to less than $140 \mu \mu \mathrm{g} . / \mathrm{ml}$. in 11 patients and to less than $100 \mu \mu \mathrm{g} . / \mathrm{ml}$. in eight of these. Among the 22 patients there are thus three groups. 
1. Latent Pernicious Anaemia (Cases 1-7).-All but one of these seven patients had a Schilling test characteristic of pernicious anaemia. Case 3 was classified as latent pernicious anaemia for reasons given above. Although six of these patients had subnormal vitamin- $B_{12}$ levels, only two showed minimal megaloblastic marrow changes at the time of the test (Cases 2 and 5). These two patients had a hypochromic anaemia, but iron therapy produced an incomplete rise in haemoglobin to $12.2 \mathrm{~g} . / 100 \mathrm{ml}$. in Case 2 and to $12.3 \mathrm{~g} . / 100 \mathrm{ml}$. in Case 5 ; after additional treatment with vitamin $\mathrm{B}_{12}$ the haemoglobin levels rose above $14.6 \mathrm{~g} . / 100 \mathrm{ml}$. in each case.

2. Normal Vitamin- $B_{12}$ Status (Cases 8-17).- In these cases Schilling tests and serum vitamin- $B_{12}$ levels were normal.

3. Reduced Serum Vitamin- $B_{12}$ Levels with Normal Schilling Tests (Cases 18-22).-While these patients showed ${ }^{58} \mathrm{Co}$-vitamin-B ${ }_{12}$ absorption within the normal range, in two instances (Case 20 and 21) a considerable rise in excreted radioactivity was produced by administration of intrinsic factor (see Table). The low serum vitamin- $\mathrm{B}_{12}$ levels in these five cases are difficult to explain. They cannot be explained by a diminished intake of vitamin $\mathrm{B}_{12}$ in the diet. The level was above $100 \mu \mu \mathrm{g} . / \mathrm{ml}$. in three cases and below $100 \mu \mu \mathrm{g} . / \mathrm{ml}$. in the remaining two (Cases 20 and 22); in both the latter cases repeat tests confirmed these results. None of the 22 patients with gastric antibody possessed antibody to thyroglobulin in their serum, as detected by the tanned-red-cell-agglutination test. Antibody to thyroid epithelial microsomes was found in the sera of one patient with latent pernicious anaemia, in five patients with normal vitamin- $\mathrm{B}_{12}$ status, and in two with reduced serum vitamin- $B_{12}$ levels with normal Schilling tests.

\section{Discussion}

Among the 22 patients with iron-deficiency anaemia, histamine-fast achlorhydria, and a positive antibody test seven were found to have the absorptive defect of vitamin- $B_{12}$ characteristic of pernicious anaemia. In two of these minimal megaloblastic changes were discovered in the bone-marrow when iron-deficiency anaemia was first recognized ; one (Case 7) developed overt pernicious anaemia one year after treatment of iron-deficiency anaemia. In three other patients the serumı vitamin $B_{12}$ was reduced without megaloblastic change. Although it is known that a reduced serum vitamin $B_{12}$ may persist for long periods without the development of megaloblastic anaemia (McIntyre et al., 1959; Beveridge et al., 1965), it is likely that most of these patients would eventually develop pernicious anaemia. Gastric antibody was found in $6 \%$ of a control series of 64 non-anaemic subjects matched for age and sex with 64 of the patients with iron-deficiency anaemia. Latent pernicious anaemia was present in approximately onethird of the iron-deficiency anaemia subjects who had gastric antibody and histamine-fast achlorhydria. If a similar proportion were found in the control group, then approximately $2 \%$ of a control group would have latent pernicious anaemia.

The finding of a positive antibody in achlorhydric irondeficiency anaemic patients is thus valuable in predicting which patients will later develop pernicious anaemia. In this whole series of 114 patients $6.2 \%$ had latent or overt pernicious anaemia ; this compares with $5.3 \%$ in the series of Beveridge et al. (1965). If a patient in this series with iron-deficiency anaemia had a histamine-fast achlorhydria, then his chances of developing pernicious anaemia were $13 \%$; if in addition his antibody test was positive, then his chances were $32 \%$. Vitamin- $B_{12}$ studies were not carried out in those patients with negative antibody tests, although some of them had achlorhydria. Since it is recognized that not much more than $10 \%$ of patients with Addisonian pernicious anaemia have a negative antibody test, it is unlikely that the estimated incidence of latent pernicious anaemia would be significantly altered by the investigation of such patients.

Five patients were also found with reduced levels of serum vitamin $B_{12}$ and normal Schilling tests. Although dietary factors played a part in the development of their irondeficiency anaemia, an assessment of the food intake of vitamin- $\mathrm{B}_{12}$ was normal in each case (see Table). It is note-

Summary of Data of 22 Patients Presenting with Iron-deficiency Anaemia and Having a Histamine-fast Achlorhydria and Gastric Parietal-cell Antibody. All except Case 7 were women. Where two or three Figures are Present for Serum Vitamin B12 or Schilling Test, the Additional Figure Represents Repeat Examinations.

\begin{tabular}{|c|c|c|c|c|c|c|c|c|c|c|c|c|}
\hline \multirow[b]{2}{*}{$\begin{array}{l}\text { Case } \\
\text { No. }\end{array}$} & \multirow[b]{2}{*}{ Age } & \multirow[b]{2}{*}{$\begin{array}{l}\text { Thyroid } \\
\text { Microsomal } \\
\text { Antibody }\end{array}$} & \multirow[b]{2}{*}{$\begin{array}{c}\text { Haemo- } \\
\text { globin } \\
\text { (g./ } \\
100 \mathrm{ml} .)\end{array}$} & \multirow{2}{*}{$\underset{(\%)}{\text { M.C.H.C. }}$} & \multirow{2}{*}{$\begin{array}{c}\text { Saturation } \\
\text { of Total } \\
\text { Iron- } \\
\text { binding } \\
\text { Capacity } \\
(\%)\end{array}$} & \multirow[b]{2}{*}{ Bone-marrow } & \multirow[b]{2}{*}{$\begin{array}{l}\text { Family } \\
\text { History of } \\
\text { Pernicious } \\
\text { Anaemia }\end{array}$} & \multirow[b]{2}{*}{$\begin{array}{l}\text { Aetiology of Iron- } \\
\text { deficiency Anaemia }\end{array}$} & \multirow[b]{2}{*}{$\begin{array}{l}\text { Dietary } \\
\text { Intake of } \\
\text { Vitamin } \\
\mathbf{B}_{12} \\
(\mu \mathrm{g} . / \text { day })\end{array}$} & \multirow[b]{2}{*}{$\begin{array}{c}\text { Serum } \\
\text { Vitamin } \\
\mathbf{B}_{12} \\
(\mu \mu \mathrm{g} . / \mathrm{ml} .)\end{array}$} & \multicolumn{2}{|c|}{ Schilling Test } \\
\hline & & & & & & & & & & & $\begin{array}{c}\text { Without } \\
\text { Intrinsic } \\
\text { Factor } \\
(\%) \\
\end{array}$ & $\begin{array}{c}\text { With } \\
\text { Intrinsic } \\
\text { Factor } \\
(\%)\end{array}$ \\
\hline 1 & 37 & Wk positive & $11 \cdot 4$ & 30 & $10 \cdot 6$ & Negative & Father & Diet. & $4 \cdot 1$ & 228 & 1.9 & $17 \cdot 7$ \\
\hline $\begin{array}{l}2 \\
3\end{array}$ & $\begin{array}{l}42 \\
43\end{array}$ & $\begin{array}{c}\text { Negative } \\
\text {, }\end{array}$ & $\begin{array}{r}8 \cdot 9 \\
10 \cdot 4\end{array}$ & $\begin{array}{l}27 \\
29\end{array}$ & $\begin{array}{r}11 \cdot 8 \\
2 \cdot 4\end{array}$ & " & Mother & Achlorhydria & $\begin{array}{r}2 \cdot 9 \\
14 \cdot 0\end{array}$ & $\begin{array}{l}66 \\
39\end{array}$ & $\begin{array}{l}1 \cdot 8 \\
3 \cdot 1\end{array}$ & $\begin{array}{c}14 \cdot 7 \\
1 \cdot 4,1 \cdot 5 \\
4 \cdot 6 *\end{array}$ \\
\hline 4 & 56 & " & $11 \cdot 5$ & 31 & 2.7 & " & $\begin{array}{l}\text { Mother. } \\
\text { Sister }\end{array}$ & $\begin{array}{l}\text { Diet. } \\
\text { Achlorhydria }\end{array}$ & $4 \cdot 7$ & $<25$ & 3.9 & $20 \cdot 7$ \\
\hline 5 & 56 & " & 9.9 & 29 & $8 \cdot 0$ & " & Mother & $\begin{array}{l}\text { Acnlornyaria } \\
\text { Hiatus hernia }\end{array}$ & 6.0 & 66 & $1 \cdot 2$ & $15 \cdot 1$ \\
\hline 6 & 64 & " & $11 \cdot 1$ & 29 & $6 \cdot 8$ & " & - & $\begin{array}{l}\text { Hiatus hernia } \\
\text { Diet. } \\
\text { Achlorhydria }\end{array}$ & $1 \cdot 7$ & 33 & $5 \cdot 8$ & $10 \cdot 0$ \\
\hline $\begin{array}{l}7 \\
8 \\
9\end{array}$ & $\begin{array}{l}65 \\
30 \\
31\end{array}$ & $\frac{\text { Positive }}{\text { Po }}$ & $\begin{array}{r}8 \cdot 0 \\
12 \cdot 0 \\
8 \cdot 4\end{array}$ & $\begin{array}{l}29 \\
31 \\
28\end{array}$ & $\begin{array}{l}12 \cdot 5 \\
16 \cdot 4 \\
10 \cdot 8\end{array}$ & "” & E & $\begin{array}{c}\text { Acnlornyaria } \\
", \\
\text { Menorrhagia }\end{array}$ & $\begin{array}{l}2 \cdot 5 \\
4 \cdot 6 \\
4 \cdot 5\end{array}$ & $\begin{array}{l}<25 \\
440 \\
196\end{array}$ & $\begin{array}{r}2 \cdot 3 \\
10 \cdot 8 \\
14 \cdot 1\end{array}$ & $\begin{array}{l}9 \cdot 8 \\
-\end{array}$ \\
\hline 10 & 41 & Wk positive & $8 \cdot 7$ & 26 & 3.7 & " & - & $\begin{array}{l}\text { Menorrnagia } \\
\text { Men. } \\
\text { Achorrhagia. } \\
\text { Achydria }\end{array}$ & $6 \cdot 3$ & 392 & $23 \cdot 2$ & - \\
\hline 11 & 42 & Positive & $10 \cdot 2$ & 31 & $15 \cdot 0$ & " & Father & $\begin{array}{l}\text { Diet. } \\
\text { Achlorhydria }\end{array}$ & $3 \cdot 6$ & 300 & $12 \cdot 0,12 \cdot 0$ & $13 \cdot 6$ \\
\hline $\begin{array}{l}12 \\
13\end{array}$ & $\begin{array}{l}43 \\
47\end{array}$ & $\begin{array}{l}\text { Negative } \\
\text { Positive }\end{array}$ & $\begin{array}{l}10 \cdot 2 \\
11 \cdot 2\end{array}$ & $\begin{array}{l}30 \\
28\end{array}$ & $\begin{array}{r}11 \cdot 3 \\
2 \cdot 4\end{array}$ & - & 二 & $\begin{array}{l}\text { Achlorhydria. } \\
\text { Menorrhagia }\end{array}$ & $\begin{array}{r}2 \cdot 7 \\
13 \cdot 9\end{array}$ & $\begin{array}{l}282 \\
176\end{array}$ & $\begin{array}{l}20 \cdot 0 \\
21 \cdot 0\end{array}$ & $\bar{z}$ \\
\hline 14 & 48 & Negative & $11 \cdot 8$ & 26 & $15 \cdot 1$ & Negative & - & $\begin{array}{l}\text { Diet. } \\
\text { Menorrhagia. } \\
\text { Achlorhydria }\end{array}$ & 3.0 & 256 & $16 \cdot 2$ & - \\
\hline 15 & 51 & " & $7 \cdot 7$ & 27 & $2 \cdot 5$ & 一 & - & $\begin{array}{l}\text { Diet. } \\
\text { Achlorhydria }\end{array}$ & - & 540 & $18 \cdot 4$ & - \\
\hline $\begin{array}{l}16 \\
17\end{array}$ & $\begin{array}{l}60 \\
64\end{array}$ & $\begin{array}{l}\text { Wk positive } \\
\text { Negative }\end{array}$ & $\begin{array}{l}9 \cdot 2 \\
9 \cdot 0\end{array}$ & $\begin{array}{l}28 \\
26\end{array}$ & $\begin{array}{l}2 \cdot 7 \\
2 \cdot 5\end{array}$ & $\begin{array}{c}\text { Negative } \\
\text { "y }\end{array}$ & 二 & Hiatus" hernia & $\begin{array}{l}2 \cdot 5 \\
1 \cdot 4\end{array}$ & $\begin{array}{l}200 \\
228\end{array}$ & $\begin{array}{l}16 \cdot 8 \\
14 \cdot 7\end{array}$ & 二 \\
\hline 18 & 43 & ” & $8 \cdot 8$ & 26 & 0.0 & ” & - & $\begin{array}{l}\text { Diet. } \\
\text { Achlorhydria }\end{array}$ & $3 \cdot 8$ & 102 & $16 \cdot 0$ & - \\
\hline $\begin{array}{l}19 \\
20 \\
21 \\
22\end{array}$ & $\begin{array}{l}44 \\
48 \\
56 \\
69\end{array}$ & $\begin{array}{l}\text { Positive } \\
\text { Negative }\end{array}$ & $\begin{array}{r}4 \cdot 5 \\
9 \cdot 0 \\
10 \cdot 8 \\
11 \cdot 3\end{array}$ & $\begin{array}{l}19 \\
27 \\
30 \\
33\end{array}$ & $\begin{array}{r}1.9 \\
14.9 \\
9 \cdot 0 \\
13.6\end{array}$ & $\begin{array}{l}\text { "' } \\
\text { "' }\end{array}$ & $\begin{array}{l}\text { Mother } \\
\text { Sister }\end{array}$ & ", & $\begin{array}{l}2 \cdot 8 \\
5 \cdot 0 \\
4 \cdot 0 \\
4 \cdot 8\end{array}$ & $\begin{array}{c}112 \\
60,98,68 \\
138 \\
60,98\end{array}$ & \begin{tabular}{|c|}
$20 \cdot 1$ \\
$11 \cdot 4$ \\
$11 \cdot 4$ \\
$18 \cdot 1,18 \cdot 4$
\end{tabular} & $\begin{array}{l}\overline{16 \cdot 3} \\
19 \cdot 4 \\
23 \cdot 5\end{array}$ \\
\hline
\end{tabular}


worthy that, despite normal initial results, absorption of ${ }^{58}$ Co-vitamin- $\mathrm{B}_{12}$ was improved by intrinsic factor in Cases 20 and 21 (see Table). It may be that this group contains patients at an early stage in the development of pernicious anaemia still capable of absorbing normally an $0.5-\mu \mathrm{g}$. dose of radioactive vitamin $B_{12}$.

The development of pernicious anaemia in patients with a past history of iron-deficiency anaemia may be explained on an immunological basis, since it is probable that such cases arise from the group of achlorhydric iron-deficiency anaemic patients with a positive antibody test. The histological changes affecting the stomach in pernicious anaemia and achlorhydric iron-deficiency anaemia may be equally severe (Davidson and Markson, 1955), and while it is recognized that the presence of a tissue auto-antibody does not necessarily have any pathogenic significance, it is clear that the antibody is associated with the changes of chronic gastritis (Adams et al. 1964; Coghill et al., 1965).

It is of considerable interest that no fewer than four of the seven subjects found to have latent pernicious anaemia had a family history of pernicious anaemia, in contrast to only one (Case 11) of the 10 patients who did not have latent pernicious anaemia. This observation has been pursued by investigating the incidence of gastric antibody in 76 relatives of six of the patients with latent pernicious anaemia and in 72 relatives of five of the patients without latent pernicious anaemia. Ten of the 76 relatives of the latent-pernicious-anaemia propositi possessed the gastric antibody in their serum, but only two of the 72 relatives of propositi without latent pernicious anaemia possessed the gastric antibody, a difference which is statistically significant $(\mathrm{P}<0.05)$ (McFadyen et al., 1966). Te Velde et al. (1964) found the gastric antibody in $20 \%$ of a large group of relatives of patients with pernicious anaemia compared with $6 \%$ in a control series. The familial association of irondeficiency anaemia and pernicious anaemia may thus be due to a genetically determined disorder of immunological tolerance present in both iron-deficient patients with latent pernicious anaemia and in patients with frank pernicious anaemia.

McFadyen et al. (1966) have suggested that in the patients with latent pernicious anaemia the atrophic gastritis was initiated by genetically determined immunological mechanisms but that in the patients without latent pernicious anaemia the atrophic gastritis was caused by iron-deficiency anaemia and that the gastric antibodies were formed as a result of damage to gastric mucosa, a mechanism which would be compatible with the absence of a genetic background. Since latent pernicious anaemia occurred only in the group with the genetic background, it may be presumed that the genetically determined immunological disorder has been of greater severity or of longer duration than that which has been acquired in later life.

A patient with iron-deficiency anaemia has thus approximately a $6 \%$ chance of developing pernicious anaemia. To predict such cases it is necessary to determine gastric acidity by means of an augmented histamine test meal (Kay, 1953), or, if this is not possible, a tubeless test of gastric function such as the Diagnex test (Bock and Witts, 1961). If free acid is present no further investigation of vitamin- $B_{12}$ status is required. If there is a histamine-fast achlorhydria the serum should be tested for parietal-cell antibodies or the serum vitamin- $B_{12}$ level should be measured, whichever of these procedures is the more convenient. The precise detection of latent pernicious anaemia can then be achieved, in patients still under suspicion, by more definitive measures such as intrinsic-factor assay of the gastric juice or the Schilling test.

\section{Summary}

Patients with iron-deficiency anaemia have an increased liability to develop Addisonian pernicious anaemia, and it is important to detect such iron-deficient patients at risk.

From 114 patients with iron-deficiency anaemia 22 were found who also had a histamine-fast achlorhydria and gastric parietal-cell antibodies in the serum.

Tests of radioactive vitamin- $B_{12}$ absorption and serum vitamin- $B_{12}$ levels have been carried out in these 22 patients to determine the incidence of latent pernicious anaemia. Seven (32\%) had latent pernicious anaemia, $10(45 \%)$ had normal vitamin- $B_{12}$ status, and five $(23 \%)$ had reduced levels of serum vitamin $\mathrm{B}_{12}$ but normal ${ }^{58} \mathrm{Co}$-labelled vitamin $\mathrm{B}_{12}$ absorption. Four of the seven subjects with latent pernicious anaemia had a family history of pernicious anaemia, while only one of the 10 patients with normal vitamin- $B_{12}$ status had such a family history.

A patient with iron-deficiency anaemia has a $6 \%$ chance of developing pernicious anaemia, but this risk increases to $32 \%$ if histamine-fast achlorhydria and gastric parietal-cell antibodies are also present.

A screening procedure for the detection of latent pernicious anaemia among iron-deficiency anaemic patients is suggested.

We are indebted to Dr. J. F. Adams for serum vitamin-B $B_{12}$ estimations and for the assay of intrinsic factor in gastric juice. We are grateful to Dr. H. E. Hutchison for haematological measurements and to Miss $M$. Black for technical assistance. The work was aided by a grant from the Advisory Committee on Medical Research, Department of Health for Scotland, and from Ciba (Research Division), Horsham, Sussex.

\section{REFERENCES}

Adams, J. F., Glen, A. I. M., Kennedy, E. H., MacKenzie, I. L., Morrow,'J. M., Anderson, J. R., Gray, K.' G., and Middleton,

Beveridge, B. R., Bannerman, R. M., Evanson, J. M., and Witts, L. J. (1965).. Quart. F. Med., 34, 145.

Bock, O. A. A., and Witts, L. J. (1961). Brit. med. 7., 2, 665.

Callender, S. T., and Denborough, M. A. (1957). Brit. F. Haemat., 3, 88.

Coghill, N. F., Doniach, D., Roitt, I. M., Mollin, D. L., and Williams, A. W. (1965). Gut, 6, 48.

agg, J. H., Goldberg, A., Anderson, J. R., Beck, J. S., and Gray, K. G. (1964). Brit. med. F., 1, 1349

Davidson, W. M. B., and Markson, J. L. (1955). Lancet, 2, 639.

Faber, K., and Gram, H. C. (1924). Arch. intern. Med., 34, 658.

Fulthorpe, A. J., Roitt, I. M., Doniach, D., and Couchman, K. (1961). 7. clin. Path., 14, 654 .

Gottlieb, C., Lau, K., Wasserman, L. R., and Herbert, V. (1965). Blood, 25, 875 .

Hutner, S. H., Bach, M. K., and Ross, G. M. (1956). F. Protozool., 3,101 .

Kaufmann, O., and Thiessen, K. (1939). Z. klin. Med., 136, 474.

Kay, A. W. (1953). Brit. med. 尹., 2, 77.

McFadyen, I. J. Goldberg, A., Dagg, J. H., and Anderson, J. R. (1966). Brit. $尹$. Haemat. In press. McIntyre, P. A., Hahn, R., Conley, C. L., and Glass, B. (1959). Bull.
fohns Hopk. Hosp., 104, 309.

Maclachlan, W. W. G., and Kline, F. M. (1926). Amer. F. med. Sci., 172, 533.

Schilling, R. F. (1953). 7. Lab. clin. Med., 42, 860

Taylor, K. B., Roitt, I. M., Doniach, D., Coughman, K. G., and Shapland, C. (1962). Brit. med. F., $1,1349$.

te Velde, K., Abels, J., Anders, G. J. P. A., Arends, A., Hoedemaeker, Ph. J., and Nieweg, H. O. (1964). \%. Lab. clin. Med., 64, 177.

Witts, L. J. (1930). Guy's Hosp. Rep., 80, 253. 